\title{
PENGARUH LABA BERSIH DAN ARUS KAS OPERASI TERHADAP DIVIDEN TUNAI PERUSAHAAN KONSTRUKSI DI BEI TAHUN 2016-2019
}

\author{
${ }^{1}$ Marismiati, ${ }^{2}$ Kurratul Aini \\ Program Studi D4 Akuntansi Keuangan \\ Politeknik Pos Indonesia \\ marismiati03@gmai.com, kurratulaini412@gmail.com
}

\begin{abstract}
ABSTRAK
Untuk membayar dividen suatu perusahaan harus menganalisis beberapa faktor yang mempengaruhi alokasi laba untuk dividen atau untuk laba ditahan. Ada faktor utama yang harus dipertimbangkan, misalnya ketersediaan kas. Penelitian ini dilakukan untuk mengetahui bagaimana pengaruh laba bersih dan arus kas operasi terhadap dividen tunai baik secara masing-masing maupun bersamaan. Metode yang digunakan dalam penelitian ini adalah metode kuantitatif dengan data sekunder dan jenis perumusan masalah asosiatif yang memiliki hubungan sebab akibat. Populasi dalam penelitian ini adalah perusahaan sub sektor konstruksi yang terdaftar di BEI. Pengambilan sampel dilakukan dengan teknik purposive sampling. Teknik analisis data yang digunakan adalah uji normalitas data, analisis korelasi product moment, analisis korelasi berganda, analisis regresi linier berganda, analisis koefisien determinasi, uji t-test, dan uji f-test. Hasil penelitian ini menunjukkan bahwa secara parsial Laba bersih dan Arus Kas Operasi memiliki pengaruh yang signifikan terhadap Dividen Tunai. Secara simultan memiliki pengaruh yang signifikan terhadap Dividen Tunai.
\end{abstract}

Kata Kunci: Laba Bersih, Arus Kas Operasi, Dividen Tunai

\section{ABSTRACT}

To pay dividends, a company must analyze several factors that affect the allocation of earnings for dividends or for retained earnings. There are major factors to consider, such as cash availability. This study was conducted to determine how the effect of net income and operating cash flow on cash dividends both individually and simultaneously. The method used in this research is a quantitative method with secondary data and the type of formulation of associative problems that have a causal relationship. The population in this study is the construction sub-sector companies listed on the IDX. The sample was taken by using purposive sampling technique. The data analysis techniques used were data normality test, product momentcorrelation analysis, multiple correlation analysis, multiple linear regression analysis, determination coefficient analysis, $t$-test, and f-test. The results of this study indicate that partially net income and operating cash flow have a significant effect on cash dividends. Simultaneously has a significant influence on Cash Dividends.

Keywords: Net Profit, Operating Cash Flow, Cash Dividend 


\section{PENDAHULUAN}

Untuk membayar dividen suatu perusahaan harus menganalisis beberapa faktor yang mempengaruhi alokasi laba untuk dividen atau untuk laba ditahan. Ada faktor utama yang harus dipertimbangkan, misalnya ketersediaan kas. Hal ini dikarenakan, walaupun perusahaan memperoleh laba namun jika uang kas tidak mencukupi maka ada kemungkinan perusahaan memilih menahan laba tersebut untuk diinvestasikan kembali, bukan untuk diberikan kepada pemegang saham dalam bentuk dividen.

Dikutip dari (www.market.bisnis.com pada tanggal 24 Juni 2019 Pukul 13:25 WIB) Emiten konstruksi swasta, PT Totalindo Eka Persada Tbk. tidak membagi dividen untuk kinerja keuangan 2018 dan menjadikan keuntungan tahun lalu sebagai laba ditahan. Keputusan itu dihasilkan dalam rapat umum pemegang saham tahunan (RUPST) tahun buku 2018 yang berlangsung di Jakarta, Senin (24/6/2019). Para pemegang saham telah menyetujui rencana penggunaan laba bersih Totalindo Eka Persada 2018. Direktur Totalindo Eka Persada Eko Wardoyo menjelaskan bahwa perseroan tidak membagi dividen untuk kinerja 2018. Pasalnya, kontraktor swasta itu memiliki kebutuhan dana pada 2019. "Laba ditahan untuk tambahan modal," ujarnya di Jakarta, Senin (24/6/2019). Seperti diketahui, emiten berkode saham TOPS itu membukukan pendapatan Rp1,45 triliun pada 2018. Posisi itu turun 36,40\% dibandingkan Rp2,28 triliun akhir 2017. Dari situ, perseroan mengantongi laba bersih Rp30,70 miliar pada 2018. Pencapaian itu turun tajam dari Rp206,50 miliar pada 2017. Eko mengatakan perseroan merealisasikan belanja modal Rp328 miliar pada 2018. Pada 2019, jumlah capital expenditure (capex) yang dianggarkan sekitar Rp200 miliar. "Capex dari dana sendiri dan kedua dari pendanaan pihak ketiga atau perbankan," jelasnya.

Berikut ini merupakan data pada PT Totalindo Eka Persada terkait dengan pembayaran dividen tunai kepada para pemegang saham terdapat pada tabel 1.1 berikut:

Tabel 1 Laba Bersih, Arus Kas Operasi dan Dividen Tunai Perusahaan Sub Sektor Konstruksi dan Bangunan yang Terdaftar di Bursa Efek Indonesia Periode 20172018

\begin{tabular}{|l|l|l|l|l|}
\hline Nama Perusahaan & Per & Laba Bersih & Arus Kas Operasi & Dividen Tunai \\
\hline & 2017 & Rp 206.502.063.663 & Rp (451.912.317.900) & $\begin{array}{l}\text { Tidak } \\
\text { membagikan } \\
\text { dividen tunai } \\
\text { kepada } \\
\text { para pemegang } \\
\text { saham Perseroan. }\end{array}$ \\
$\begin{array}{l}\text { PT Totalindo Eka } \\
\text { Persada, Tbk }\end{array}$ & 2018 & Rp 30.706.731.540 & Rp (283.368.170.952) & $\begin{array}{l}\text { Perseroan tidak } \\
\text { membagikan } \\
\text { dividen untuk } \\
\text { tahun buku tahun } \\
\text { 2018. }\end{array}$ \\
\cline { 2 - 5 } & & & & \\
\hline
\end{tabular}

Berdasarkan tabel 1.1 diatas dapat terlihat PT Totalindo Eka Persada, Tbk tidak membagikan dividen kepada para pemegang saham untuk periode 2017-2018. PT Totalindo Eka Persada, Tbk pada tahun 2017 menghasilkan laba bersih sebesar Rp 206.502.063.663 dan pada tahun 2018 mengalami penurunan laba bersih menjadi Rp 30.706.731.540. Kemudian perseroan membukukan defisit arus kas dari aktivitas operasi sebesar Rp (451.912.317.900) pada tahun 2017 dan dibandingkan defisit tahun sebelumnya, perseroan membukukan defisit arus kas dari aktivitas operasi sebesar Rp283 miliar pada tahun 2018. Selanjutnya, perseroan tidak membagikan dividen untuk tahun buku 2017-2018.

Menurut PSAK No. 2 paragraf 12 menyatakan sebagai berikut. "Hubungan dari arus kas operasi terhadap dividen tunai yaitu apabila kegiatan operasi perusahaan 
meningkat maka laba bersih yangdiperoleh perusahaan akan meningkat sehingga perusahaan dapat membagikan dividen tunai yang besar, karena perusahaan membayar dividen tunai menggunakan uang kas, maka perusahaan harus memiliki kastersediaan.

Jadi jika arus kas operasi besar, dividen tunai yang ditetapkan juga besar karena perusahaan memiliki ketersediaan kas. Oleh karena itu, jika perusahaan profitable namun mengalami defisit arus kasdapat merupakan indikasi bahwa perusahaan mengalami masalah keuangan dan dikhawatirkan tidak mampumengembalikan pinjaman kepada kreditor maupun membayar dividen kepada investor.

Penelitian mengenai pengaruh laba bersih dan arus kas operasi terhadap dividen tunai sudah pernah dilakukan oleh penelitian terdahulu dan sekarang menjadi referensi dalam penelitian ini, diantaranya yaitu penelitian yang dilakukan oleh Sherly Rinjani dan Uswatun Hasanah dalam penelitiannya yang berjudul Pengaruh Laba Bersih dan Arus Kas Operasi terhadap Dividen Tunai pada Perusahaan Manufaktur Sub Sektor Farmasi yang terdaftar di bursa efek Indonesia periode 2013-2018, hasil penelitiannya menunjukkan bahwa pengujian mengenai pengaruh laba bersih dan arus kas operasi terhadap dividen tunai yaitu laba bersih dan arus kas operasi berpengaruh positif signifikan terhadap dividen tunai.

Berdasarkan latar belakang yang telah dipaparkan diatas, identifikasi masalah dalam penelitian ini, yaitu:

1. Bagaimana pengaruh Laba Bersih terhadap Dividen Tunai pada perusahaan sub sektor konstruksi yang terdaftar di Bursa Efek Indonesia periode 2016-2019?

2. Bagaimana pengaruh Arus Kas Operasi terhadap Dividen Tunai pada perusahaan sub sektor konstruksi yang terdaftar di Bursa Efek Indonesia periode 2016-2019?

3. Bagaimana pengaruh Laba Bersih dan Arus Kas Operasi terhadap Dividen Tunai pada perusahaan sub sektor konstruksi yang terdaftar di Bursa Efek Indonesia periode 2016-2019?

\section{KAJIAN PUSTAKA}

\section{Laba Bersih}

Menurut Kasmir (2016:303) laba bersih (net profit) merupakan laba yang telah dikurangi biaya-biaya yang merupakan beban perusahaan dalam suatu periode tertentu termasuk pajak.

\section{Arus Kas Operasi}

Menurut Sugiono dan Untung (2016:35) arus kas aktivitas operasi adalah aktivitas yang dilakukan perusahaan dalam memperoleh laba dengan menjual barang dan jasa, merupakan aktivitas rutin perusahaan.

\section{Dividen Tunai}

Menurut Kartikahadi dkk (2016:18) menyatakan "dividen tunai (cash dividend) adalah pembagian dalam bentuk kas secara proporsional kepada setiap pemegang saham.

\section{METODE PENELITIAN}

\section{Jenis Penelitian}

Metode penelitian ini menggunakan metode penelitian kuantitatif, dengan jenis penelitian assosiatif dengan bentuk hubungan kausal. Hubungan kausal merupakan hubungan yang bersifat sebab-akibat.

\section{Operasional Variabel}

Dengan judul penelitian yang telah dikemukakan yaitu "Pengaruh laba bersih dan arus kas operasi terhadap dividen tunai pada perusahaan sub sektor konstruksi yang terdaftar di Bursa Efek Indonesia" maka penelitian ini memiliki dua variabel yang 
saling berkaitan yaitu variabel bebas (Independent variable) dan variabel terikat (Dependent variable). Variabel bebas yang berkaitan dengan masalah yang akan diteliti yaitu variabel X1 adalah laba bersih dan variabel X2 adalah arus kas operasi. Variabel terikat yang berkaitan dengan masalah yang akan diteliti yaitu variabel $\mathrm{Y}$ adalah dividen tunai. Adapun tabel operasionalisasi variable sebagai berikut:

\section{Teknik Pengumpulan Data}

Data yang digunakan dalam penelitian ini merupakan data sekunder dengan pengumpulan data menggunakan teknik studi dokumentasi. Data diakses melalui situs resmi www.idx.co.id dan web resmi perusahaan. Selain teknik dokumentasi peneliti juga menggunakan studi dokumentasi sebagai acuan dan dasar teori dalam mengolah data yang dibutuhkan untuk penelitian.

\section{Populasi dan Sampel}

- Populasi yang digunakan dalam penelitian ini adalah seluruh laporan keuangan perusahaan sub sektor konstruksi yang terdaftar di Bursa Efek Indonesia, sehingga diperoleh jumlah populasi yakni 16 perusahaan.

- Sampel yang digunakan dalam penelitian ini berdasarkan metode non probability sampling dengan teknik purposive sampling, terdapat 6 perusahaan dikalikan 5 tahun periode penelitian jadi total sampel yang diteliti sebanyak 30 sampel.

\section{Teknik Analisis Data}

Penelitian ini menggunakan SPSS versi 24 dengan tujuh teknik analisis yaitu: uji normalitas, analisis korelasi product moment, analisis korelasi berganda, analisis regresi linier berganda, analisis koefisien determinasis, uji $\mathrm{T}$ dan uji $\mathrm{F}$.

\section{HASIL DAN PEMBAHASAN}

\section{Uji Normalitas Data}

Uji normalitas digunakan untuk memastikan setiap variabel memiliki distribusi normal atau tidak serta untuk memperkecil kemungkinan terjadinya bias. Didapatkan output dari hasil perhitungan uji normalitas data dengan menggunakan Test Normality Kolmogorov-Smirnov sebagai berikut :

Tabel 3 Hasil Uji Normalitas Data One-Sample Kolmogorov-Smirnov Test

\begin{tabular}{|c|c|c|}
\hline \multicolumn{3}{|c|}{ Une-Sample Koimogorov-smirnov lest } \\
\hline & & $\begin{array}{c}\text { Unstandardized } \\
\text { Residual } \\
\end{array}$ \\
\hline $\mathrm{N}$ & & 36 \\
\hline \multirow{2}{*}{ Normal Parameters ${ }^{\mathrm{a}, \mathrm{b}}$} & Mean &,- 0000119 \\
\hline & Std. Deviation & $\begin{array}{r}115362463283,74 \\
547000\end{array}$ \\
\hline \multirow[t]{3}{*}{ Most Extreme Differences } & Absolute &, 138 \\
\hline & Positive & ,138 \\
\hline & Negative &,- 110 \\
\hline Test Statistic & & , 138 \\
\hline Asymp. Sig. (2-tailed) & &, $080^{\mathrm{c}}$ \\
\hline
\end{tabular}

Dari hasil uji normalitas yang dilakukan bahwa setiap variabel memiliki nilai Asymtotic Significanted (2-tailed) sebesar 0,080 menunjukan jika nilai tersebut lebih besar dari nilai 0,05 dinyatakan terdistribusi normal. Dimana hal tersebut berdasar teori menurut Ghozali (2016:154) yang menyatakan "jika nilai signifikan lebih besar sama 
dengan (>) 0,05 maka data tersebut berdistribusi normal". Hasil uji normalitas pada penelitian ini menunjukan $0,080>0,05$ maka dengan demikian data tersebut dinyatakan berdistribusi normal. Apabila data sudah dinyatakan berdistribusi normal, maka dilanjutkan ke statistik parametris yang telah ditentukan yaitu korelasi product moment dan korelasi berganda.

\section{Analisis Korelasi Product Moment}

Analisis korelasi product moment digunakan untuk memastikan kuat atau lemahnya hubungan antara laba bersih dan arus kas operasi secara parsial terhadap dividen tunai dengan hasil sebagai berikut :

\section{Tabel 4 Hasil Analisis Korelasi Product Moment} Correlations

\begin{tabular}{|c|c|c|c|c|}
\hline & & Laba Bersih & Arus Kas Operasi & Dividen Tunai \\
\hline \multirow[t]{3}{*}{ Laba_Bersih } & Pearson Correlation & 1 & -.004 & $.708^{* *}$ \\
\hline & Sig. (2-tailed) & & .982 & .000 \\
\hline & $\mathrm{N}$ & 36 & 36 & 36 \\
\hline \multirow[t]{3}{*}{ Arus_Kas_Operasi } & Pearson Correlation & -.004 & 1 & $.464^{* *}$ \\
\hline & Sig. (2-tailed) & 982 & & .004 \\
\hline & $\mathrm{N}$ & 36 & 36 & 36 \\
\hline \multirow[t]{3}{*}{ Dividen_Tunai } & Pearson Correlation & $.708^{* *}$ & $.464^{* *}$ & 1 \\
\hline & Sig. (2-tailed) & .000 & .004 & \\
\hline & $\mathrm{N}$ & 36 & 36 & 36 \\
\hline
\end{tabular}

**. Correlation is significant at the 0.01 level (2-tailed).

Berdasarkan hasil pengolahan data korelasi product moment dapat diketahui bahwa laba bersih memiliki hubungan positive terhadap dividen tunai sebesar 0,708 dengan tingkat hubungan yang kuat karena berada pada rentang 0,60-0,799. Kemudian arus kas operasi juga memiliki hubungan positive terhadap dividen tunai sebesar 0,464 dengan tingkat hubungan yang sedang karena berada pada rentang 0,40-0,599.

\section{Analisis Korelasi Berganda}

Korelasi ganda merupakan angka yang menunjukkan arah dan kuatnya hubungan antara dua variabel independen secara bersama-sama atau lebih dengan satu variabel dependen. Terdapat hasil seperti berikut:

Tabel 5 Hasil Analisis Korelasi Berganda

\begin{tabular}{|c|c|c|c|c|}
\hline \multirow[b]{2}{*}{ Model } & \multicolumn{4}{|c|}{ Model Summary } \\
\hline & $\mathrm{R}$ & R Square & Adjusted R Square & $\begin{array}{l}\text { Std. Error of the } \\
\text { Estimate }\end{array}$ \\
\hline 1 & $.848^{\mathrm{a}}$ & .719 & .702 & 118806875084.362 \\
\hline
\end{tabular}

Sumber: Data Diolah dengan Program IBM SPSS Statistics Versi 24.0 (2020)

Dengan hasil $\mathrm{R}$ sebesar 0,848 menunjukkan laba bersih dan arus kas operasi secara simultan memiliki hubungan yang sangat kuat terhadap dividen tunai karena berada pada rentang 0,80-1,000.

\section{Analisis Regresi Linier Berganda}

Analisis ini untuk mengetahui arah hubungan antara variabel independen dengan variabel dependen apakah masing-masing variabel independen berhubungan positif atau negatif dan untuk memprediksi nilai dari variabel dependen apabila nilai independen mengalami kenaikan atau penurunan. Berikut ini adalah hasil dari analisis regresi linear berganda yang telah dilakukan oleh peneliti:

Tabel 6 Analisis Regresi Berganda

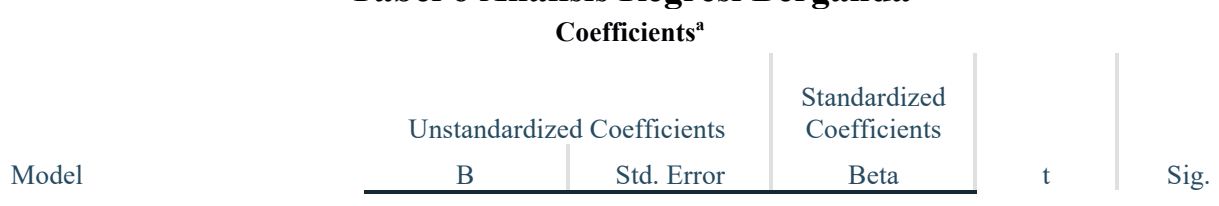




\begin{tabular}{ll|r|r|r|r|r}
\hline 1 & (Constant) & 57147715891.5 & 24561374588.3 & & 2.327 & .026 \\
\cline { 2 - 7 } & Laba_Bersih & .131 & .06 & .710 & 7.699 & .000 \\
\cline { 2 - 7 } & Arus_Kas_Operasi & .040 & .008 & .467 & 5.064 & .000 \\
\hline a. Dependent Variable: Dividen_Tunai & & & &
\end{tabular}

Sumber: Data Diolah dengan Program IBM SPSS Statistics Versi 24.0 (2020)

Dari hasil pengolahan data menggunakan SPSS 24.0, maka didapatkan persamaan sebagai berikut :

$$
\mathrm{Y}=5,715+0,131 \mathrm{X}_{1}+0,40 \mathrm{X}_{2}
$$

Dari persamaan tersebut, dapat diartikan sebagai berikut:

1. Jika variabel laba bersih (X1) dan arus kas operasi (X2) nilainya adalah 0 , maka nilai variabel dividen tunai $(\mathrm{Y})$ adalah sebesar konstanta atau sebesar 5,715.

2. Koefisien regresi variabel laba bersih (X1) sebesar 0,131, artinya jika variabel independen lain nilainya tetap dan laba bersih mengalami kenaikan 1, maka dividen tunai akan mengalami kenaikan sebesar 0,131 . Karena koefisien bernilai positif maka terjadi hubungan positif pula antara laba bersih (X1) terhadap dividen tunai (Y). Jadi kenaikan laba bersih (X1) mengakibatkan kenaikan juga pada dividen tunai $(\mathrm{Y})$.

3. Koefisien regresi variabel arus kas operasi (X2) sebesar 0,40artinya jika variabel independen lain nilainya tetap dan arus kas operasi mengalami kenaikan 1, maka dividen tunai akan mengalami peningkatan sebesar 0,40. Karena koefisien bernilai positif maka terjadi hubungan positif pula antara arus kas operasi (X2) terhadap dividen tunai (Y). Jadi kenaikan arus kas operasi (X2) mengakibatkan kenaikan juga pada dividen tunai (Y).

\section{Analisis Koefisien Determinasi}

Koefisien determinasi digunakan untuk mengetahui besarnya pengaruh variabel independen yaitu laba bersih (X1) dan arus kas operasi (X2) terhadap variabel dependen yaitu dividen tunai. Diperoleh hasil analisis koefisien determinasi sebagai berikut :

\section{Tabel 7 Koefisien Determinasi}

\begin{tabular}{|c|c|c|c|c|}
\hline \multirow[b]{2}{*}{ Model } & \multicolumn{3}{|c|}{ Model Summary } & \multirow[b]{2}{*}{$\begin{array}{l}\text { Std. Error of the } \\
\text { Estimate }\end{array}$} \\
\hline & $\mathrm{R}$ & R Square & Adjusted R Square & \\
\hline 1 & $.848^{\mathrm{a}}$ & .719 & .702 & 118806875084.362 \\
\hline
\end{tabular}

Sumber: Data Diolah dengan Program IBM SPSS Statistics Versi 24.0 (2020)

Berdasakan tabel diatas dapat diketahui bahwa R Square adalah sebesar 0,719. Nilai ini dikenal dengan koefisien determinasi (Kd) yang dapat dihitung sebagai berikut :

$\mathrm{Kd}=\mathrm{r} 2 \times 100 \%$

$\mathrm{Kd}=0,719 \times 100 \%$

$\mathrm{Kd}=71,9 \%$

Berdasarkan diperoleh R2 (R Square) sebesar 0,719 atau 71,9\%. Hal ini menunjukkan bahwa persentase pengaruh variabel independen laba bersih dan arus kas operasi (X1 dan X2) terhadap variabel dependen dividen tunai $(\mathrm{Y})$ adalah 71,9\% sedangkan sisanya sebesar $28,1 \%$ dipengaruhi oleh faktor lainnya yang tidak dimasukkan ke dalam penelitian ini.

\section{Uji Hipotesis t-test}

Pengujian hipotesis dalam penelitian ini menggunakan uji-t untuk menunjukan seberapa jauh pengaruh satu variabel independen secara individual dalam menerangkan variasi-variasi variabel dependen. Hasil pengujian dapat dilihat pada tabel berikut ini:

\section{Tabel 8 Uji Hipotesis t-test}




\begin{tabular}{|c|c|c|c|c|c|c|}
\hline \multicolumn{7}{|c|}{ Coefficients $^{\mathrm{a}}$} \\
\hline \multirow[b]{2}{*}{ Model } & & \multicolumn{2}{|c|}{ Unstandardized Coefficients } & \multirow{2}{*}{$\begin{array}{c}\text { Standardized } \\
\text { Coefficients } \\
\text { Beta } \\
\end{array}$} & \multirow[b]{2}{*}{$\mathrm{t}$} & \multirow[b]{2}{*}{ Sig. } \\
\hline & & $\mathrm{B}$ & Std. Error & & & \\
\hline 1 & (Constant) & $\begin{array}{r}57147715891.50 \\
6 \\
\end{array}$ & $\begin{array}{r}24561374588.39 \\
0 \\
\end{array}$ & & 2.327 & .026 \\
\hline & Laba_Bersih & .131 & .017 & .710 & 7.699 & .000 \\
\hline & Arus_Kas_Operasi & .040 & .008 & 467 & 5.064 & .000 \\
\hline
\end{tabular}

a. Dependent Variable: Dividen_Tunai

Sumber: Data Diolah dengan Program IBM SPSS Statistics Versi 24.0 (2019)

Hasil uji t dengan menggunakan IBM SPSS Statistic 24.0 dalam tabel diatas antara variabel Laba Bersih terhadap Dividen Tunai menunjukkan bahwa nilai t-hitung sebesar 7,699. Dengan melihat pada t-tabel jumlah data $n=36$ dan $(\mathrm{df})=\mathrm{n}-\mathrm{k}$ atau $36-3=$ 33 pada tingkat kesalahan $\alpha=0,05$ dengan pengujian dua pihak maka diperoleh t-tabel sebesar 2,052. Hal ini menujukkan bahwa t-hitung $\geq \mathrm{t}$-tabel maka Ha diterima dan Ho ditolak. Artinya secara parsial terdapat pengaruh signifikan antara laba bersih terhadap dividen tunai.

Sedangkan untuk variabel arus kas operasi menunjukkan bahwa nilai t-hitung sebesar 5,064. Dengan melihat pada t-tabel jumlah data $n=36$ dan (df) $=n-k-1$ atau 36-2$1=33$ pada tingkat kesalahan $\alpha=0,05$ dengan pengujian dua pihak maka diperoleh $\mathrm{t}$-tabel sebesar 2,052. Ini menunjukkan bahwa hal ini menujukkan bahwa t-hitung $\geq \mathrm{t}$-tabel maka Ha diterima dan Ho ditolak. Artinya secara parsial terdapat pengaruh signifikan antara arus kas operasi terhadap dividen tunai. bentuk kurva:

Berikut adalah daerah penerimaan dan penolakan Ho apabila di sajikan dalam

\section{Kurva Uji t}

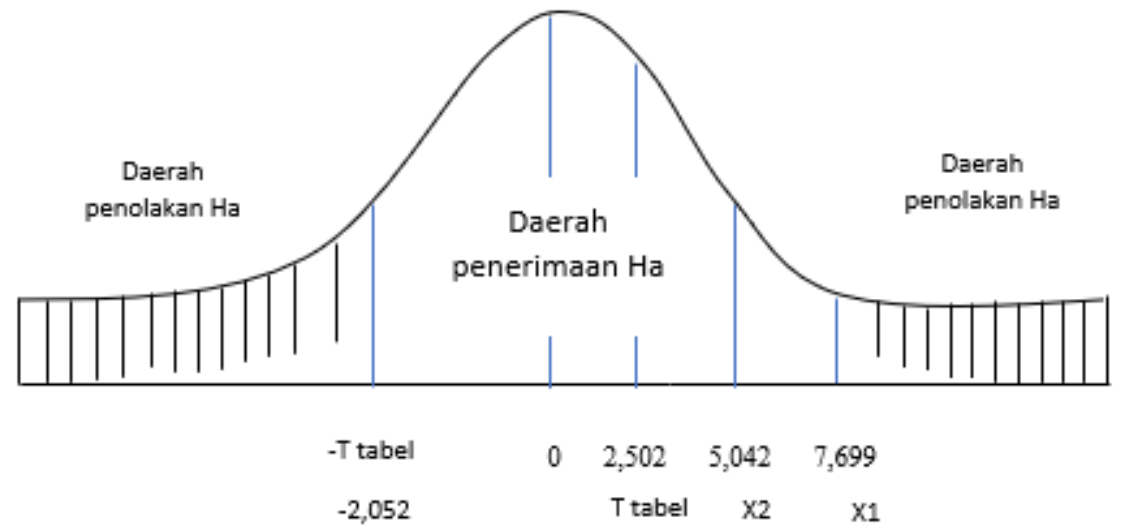

\section{Uji Hipotesis F-test}

\section{Gambar 1 Kurva Uji Dua Pihak (Uji T)}

Uji $\mathrm{F}$ ini digunakan untuk mengetahui apakah variabel independen laba bersih (X1) dan arus kas operasi (X2) secara bersama-sama berpengaruh secara signifikan terhadap variabel dependen dividen tunai (Y). Berikut ini adalah tabel hasil dari uji F:

\section{Tabel 9 Uji Hipotesis F-Test}

\begin{tabular}{|c|c|c|c|c|c|c|}
\hline \multicolumn{7}{|c|}{ ANOVA $^{a}$} \\
\hline Model & & Sum of Squa & & Mean Square & $\mathrm{F}$ & Sig. \\
\hline 1 & Regression & $\begin{array}{r}1194357631480424 \\
400000000.000\end{array}$ & 2 & $\begin{array}{r}59717881574021 \\
2200000000.000\end{array}$ & 42.308 & $.000^{\mathrm{b}}$ \\
\hline
\end{tabular}




\begin{tabular}{l|r|r|r|r|r}
\hline Residual & 4657974277212730 & 33 & 14115073567311 & & \\
\hline & 00000000.000 & & 304000000.000 & \\
\hline Total & 1660155059201697 & 35 & & & \\
& 400000000.000 & & & & \\
\hline
\end{tabular}

a. Dependent Variable: Dividen_Tunai

b. Predictors: (Constant), Arus Kas Operasi, Laba Bersih

Sumber: Data Diolah dengan Program IBM SPSS Statistics Versi 24.0 (2019)

Dari hasil derajat kebebasan (df) dapat dilihat dalam F-tabel sebesar 2,052, sehingga dapat ditentukan bahwa nilai F-hitung lebih besar dari nilai F-tabel $(42,308>2,052)$ dengan nilai signifikansi adalah sebesar 0,000 dibawah dari 5\% $(\alpha=$ 0,05). Dari hasil tersebut dapat dikatakan bahwa Laba Bersih dan Arus Kas Operasi secara bersama-sama (simultan) berpengaruh signifikan terhadap Dividen Tunai. Berikut adalah daerah penerimaan dan penolakan Ho apabila di sajikan dalam bentuk kurva:

Kurva Uji $f$

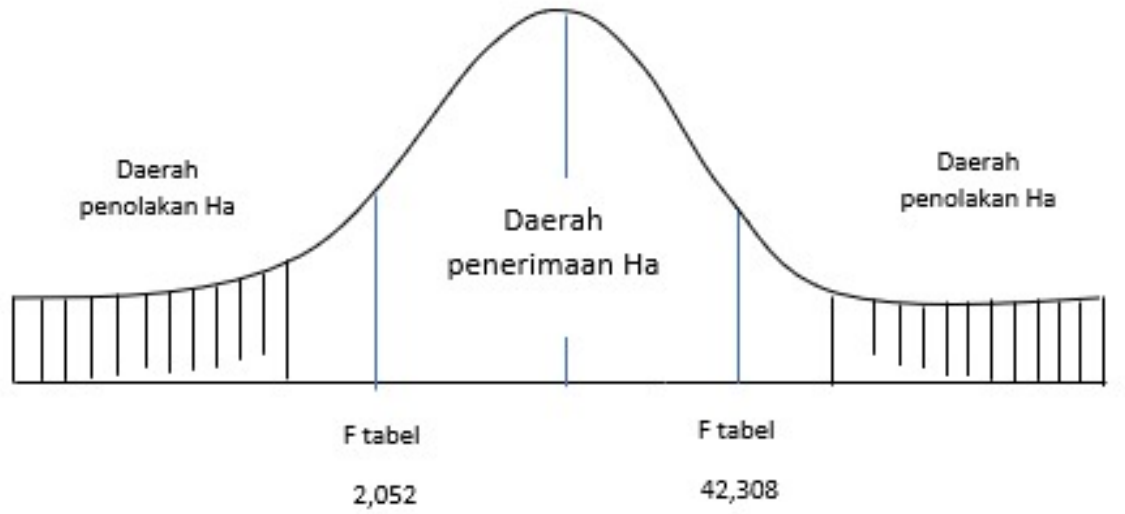

Gambar 2 Kurva Uji Dua Pihak (Uji F)

\section{PEMBAHASAN}

\section{Pengaruh Laba Bersih Terhadap Dividen Tunai}

Hasil pengujian analisis hipotesis $T$-test secara parsial laba bersih memiliki $\mathrm{T}$ hitung sebesar 7,699 dan T Tabel 2,042 yang artinya T Hitung $>$ T Tabel. Maka dapat disimpulkan bahwa hipotesis $\mathrm{Ha}_{1}$ diterima dan $\mathrm{Ho}_{1}$ ditolak. Sehingga secara statistic dapat dinyatakan bahwa, laba bersih secara parsial terdapat pengaruh terhadap dividen tunai.

Berdasarkan teori menurut Hery (2016:41) menyatakan "laba bersih adalah angka terakhir dalam perhitungan laba rugi dimana untuk mencarinya laba operasi ditambah pendapatan lain-lain dikurangi dengan beban lain-lain." Laba bersih perusahaan mencerminkan kemampuan perusahaan dalam mengelola perusahaan. Perusahaan yang mampu menyisihkan sebagian besar labanya untuk dibagikan sebagai dividen kas dibandingkan menyisihkan sebagian laba ditahan dianggap sebagai perusahaan yang menguntungkan dan memiliki prospek yang bagus bagi para investor. Hal ini menunjukan bahwa data laba bersih pada perusahaan mengalami peningkatan maka akan memberikan peningkatan juga terhadap dividen tunai. Ini artinya investor dapat menjadikan data laba bersih sebagai salah satu pertimbangan untuk mendapatkan dividen tunai.

\section{Pengaruh Arus Kas Operasi Terhadap Dividen Tunai}

Hasil pengujian analisis hipotesis T-test secara parsial arus kas operasi memiliki $\mathrm{T}$ hitung sebesar 5,064 dan T Tabel 2,042 yang artinya $\mathrm{T}$ hitung $>\mathrm{T}$ tabel. Maka dapat 
disimpulkan bahwa hipotesis $\mathrm{Ha}_{2}$ diterima dan $\mathrm{Ho}_{2}$ ditolak. Sehingga secara statistic dapat dinyatakan bahwa, arus kas operasi secara parsial terdapat pengaruh terhadap dividen tunai.

Menurut PSAK No. 2 paragraf 12 menyatakan sebagai berikut. "Hubungan dari arus kas operasi terhadap dividen tunai yaitu apabila kegiatan operasi perusahaan meningkat maka laba bersih yangdiperoleh perusahaan akan meningkat sehingga perusahaan dapat membagikan dividen tunai yang besar, karena perusahaan membayar dividen tunai menggunakan uang kas, maka perusahaan harus memiliki ketersediaan kas."

Maka hubungan dari arus kas operasi terhadap dividen tunai apabila kegiatan operasi perusahaan meningkat, laba bersih yang diperoleh perusahaan akan meningkat sehingga perusahaan dapat membagikan dividen tunai yang besar.

\section{Pengaruh Laba Bersih dan Arus Kas Operasi Terhadap Dividen Tunai}

Berdasarkan hasil analisis uji hipotesis F-test secara simultan laba bersih dan arus kas operasi memiliki F hitung sebesar 42,308 dan F Tabel 2,042 yang artinya F Hitung > F Tabel. Maka dapat disimpulkan bahwa hipotesis $\mathrm{Ha}_{3}$ diterima dan $\mathrm{Ho}_{3}$ ditolak. Sehingga secara statistic dapat dinyatakan bahwa, laba bersih dan arus kas operasi secara simultan terdapat pengaruh signifikan terhadap dividen tunai.

Menurut PSAK No. 2 paragraf 12 menyatakan sebagai berikut. "arus kas yang berasal dari aktivitas operasi merupakan indikator yang menentukan apakah dari kegiatan operasi perusahaan dapat menghasilkan arus kas yang cukup untuk melunasi pinjaman, memelihara kemampuan operasi perusahaan, membayar dividen, dan melakukan investasi baru tanpa mengandalkan sumber pendanaan dari luar."

Maka hubungan dari laba bersih dan arus kas operasi terhadap dividen tunai yaitu apabila kegiatan operasi perusahaan meningkat maka laba bersih yang diperoleh perusahaan akan meningkat sehingga perusahaan dapat membagikan dividen tunai yang besar. Hal ini membuktikan bahwa laba bersih dan arus kas operasi sangat mempengaruhi dividen tunai yang dapat menjadi bahan pertimbangan bagi investor.

\section{KESIMPULAN}

Berdasarkan identifikasi masalah, hipotesis dan hasil pengujian yang telah dilakukan untuk mengetahui pengaruh Laba Bersih dan Arus Kas Operasi terhadap Dividen Tunai maka dapat disimpulkan sebagai berikut:

1. Hasil uji hipotesis antara laba bersih dan dividen tunai menunjukan bahwa terdapat pengaruh yang signifikan antara laba bersih terhadap dividen tunai pada perusahaan sub sektor konstruksi yang terdaftar di Bursa Efek Indonesia tahun 2016-2019.

2. Hasil uji hipotesis antara arus kas operasi dan dividen tunai menunjukan bahwa terdapat pengaruh yang signifikan antara arus kas operasi terhadap dividen tunai pada perusahaan sub sektor konstruksi yang terdaftar di Bursa Efek Indonesia tahun 2016-2019.

3. Hasil uji hipotesis antara laba bersih dan arus kas operasi terhadap dividen tunai menunjukan bahwa terdapat pengaruh yang signifikan antara laba bersih terhadap dividen tunai pada perusahaan sub sektor konstruksi yang terdaftar di Bursa Efek Indonesia tahun 2016-2019. 


\section{DAFTAR PUSTAKA}

Hery (2016). Analisis Laporan Keuangan. Jakarta: Grasindo

Ikatan Akuntansi Indonesia (2015).Pernyataan Standar Akuntansi Keuangan Umum. Jakarta: Salemba Empat.

Kasmir (2016).Analisis Laporan Keuangan cetakan 9. Jakarta: Raja Grafindo Persada

Kartikahadi, dkk (2016). Akuntansi Keuangan Berdasarkan SAK Berbasis IFRS. Jakarta: Salemba Empat 